\title{
Presidential Nominations Since Party Reform
}

\author{
Leon D. Epstein, University of Wisconsin-Madison
}

\begin{abstract}
The much criticized presidential nominating system of 1972-1992 looks more defensible when it is compared with alternative systems. For analytical purposes, the proposed or conceivable options are discussed under six rubrics, ranging from least to most participatory. Each alternative, it is argued, is either politically unrealistic or less desirable than the present system. An advantage of that system, as we know from the experience of the last twenty years, is that it allows incremental changes that might be more difficult to make under a nationally legislated plan. Thus, improvements can be contemplated by states and parties without a virtually irreversible transformation of the system.
\end{abstract}

In the year following the long march of presidential candidates toward nomination and election, we are less urgently concerned with the way party nominees are chosen than we were just before and during the nominating season. Yet, we readily recall from 1992 that the selection system itself was blamed for a perceived paucity of major candidates seeking the Democratic nomination, and that an Independent, Ross Perot, ignored the party nomination route but won almost one-fifth of the popular vote in the November election. Hence, even out of season, the current system for nominating presidential candidates is worth attention. In behalf of that system, I present an argument that can be summarized in language similar to Winston Churchill's about democracy: it is the worst system except for all the others. Accordingly, I devote much of this paper to the disadvantages of alternative nominating systems. At the start, however, I want to recognize certain positive features of the current system.

\section{I}

To say anything favorable, if only in comparative terms, about the presidential nominating system of the last twenty years is to step outside the mainstream of opinion among political scientists and publicists. We are familiar with their objections: the nominating process is inordinately long, expensive, and arduous; it is heavily influenced by fortuitous events and the presentation of those events by the news media; it fails to represent citizens

LEON D. EPSTEIN is Hilldale Professor Emeritus at the University of Wisconsin, Madison, and is a past President of the American Political Science Association.

The American Review of Politics, Vol. 14, Summer, 1993: 149-162

(C)1993 The American Review of Politics 
who cannot vote in crucial early contests and many others who choose not to vote in any primaries; it is insufficiently responsive to peer-group judgments of candidates by their political colleagues; it tends to exclude significant potential candidates because of their office-holding responsibilities or their distaste for a year's manic campaigning; and it works against the choice of a consensual nominee able to win a general election or govern successfully if elected. Political scientists who make all or some of these objections disagree about alternatives to the present system. Often, however, they express a preference for reducing the impact of voters in primaries and increasing that of party activists, party leaders, or both. The preference points toward a revised version of the mixed system that prevailed for about sixty years prior to 1972. Something like it is discussed by Nelson Polsby (1983) in his formidably argued analysis of the post-1968 reforms.

Like most other critics of the 1972-1992 nominating system, Polsby is concerned principally with the Democratic party's difficulties under that system. Not only did the Democrats lose all but one of the presidential elections in the twenty years before 1992, but the election that they won, in 1976, produced a president who appeared to govern ineffectively and who failed to win re-election. In obvious contrast, Republicans have had no similar cause for complaint. And the few Republican political scientists whom I know - there are not many to know-remained outside the critical chorus. Winning or losing most of the presidential elections, however, may not be the only way to account for the inter-party difference in volume and degree of criticism. One might argue that because the Democratic party is the more heterogeneous of the two parties it is less able to succeed in nominating a consensual choice by a popular participatory process. Or Democrats may simply feel more responsible for the post-1968 system; their new national rules, requiring caucuses to be open and fairly participatory, made caucuses less congenial to political leaders and thus unintentionally encouraged state legislatures and state parties to adopt presidential primaries. Once the issue was raised in the 1970s, Republicans as well as Democrats seemed to prefer primaries to caucuses for the same reasons that they had for using primaries to nominate for most non-presidential offices.

Conceivably, Republicans might come to dislike the system if they should lose another one or two presidential elections after 1992. And some Democrats might even come to appreciate the system if President Clinton turns out to be successful in office and then re-elected, as Jimmy Carter was not. Most political scientists, however, are so committed to an adversely critical view that they are unlikely converts even after any projected Clinton success - just as they are unlikely to be converted by my arguments. 
It is time to specify more precisely what I am treating as the essentials of the 1972-1992 presidential nominating system. So far I have done little more than call attention to the dominance of primaries. The meaning of that dominance is that most national party convention delegates are committed to presidential candidates by those primaries, and that, in practice, a particular candidate wins enough committed delegates, mainly but not solely from those primaries, to be proclaimed the nominee before a convention ratifies the apparently popular choice. Nothing, to be sure, formally guarantees such a pre-convention determination, but its regular occurrence over twenty years, except perhaps in the 1976 Republican contest, causes us to assume its overwhelming likelihood. Even increasingly stringent Democratic proportional representation rules, along with the addition of a substantial minority of unpledged ex officio delegates, have not prevented winners of primaries from capturing nominations before conventions begin. Hence, I regard the pre-convention determination as a crucial element of the system. If it ceased to occur, not just once in aberrant circumstances but so that we no longer expected it to occur, then by definition we would have a different system. Another essential of the present system is its irregular serial schedule of primaries and other delegate-choosing events. Within national party guidelines, states and state parties choose not only the method of delegate selection (primary or caucus-convention) but also the dates for their delegate-election events. The result, as we know, is a four-month season during which particular primaries and caucuses can be timed and/or clustered for maximum impact.

Neither any particular timing, like New Hampshire's, nor any clustering (like that of several southern states), should be treated as a defining characteristic of the system, but the serial scheduling itself does distinguish the present system from a single national primary. Add to my short list of essentials the toleration of various practices that states and state parties adopt within national party guidelines. Besides deciding whether to use primaries or caucuses, states and state parties differ considerably as to types of primaries (closed or open) and types of caucuses. Even within a given state, Republicans and Democrats occasionally differ. And, of course, Republicans generally are less restricted than Democrats by national party rules. Their delegations need not conform to fixed affirmative-action guidelines, nor do they have to be chosen by proportional representation. Republicans in some states still use winner-take-all principles. Thus, a good many of the most controversial Democratic practices are not among what I term the essentials of the contemporary nominating system.

An essential of the system that does need to be emphasized is its large number of participants. Even caucuses in certain states are attended by 
100,000 or 200,000 people, but they are dwarfed by voter turnouts in the 35 to 40 states now holding presidential primaries. In 1988, for example, Pomper $(1989,41,61)$ shows about 23 million voting in Democratic primaries and almost 12 million in Republican primaries, though the latter were noncompetitive after the early events. Note that the Democratic total is over half of the general election vote of 41.8 million polled by the party nominee, Michael Dukakis. Even in 1992, when primary turnouts were down and general election turnouts were up, over 20 million votes were cast in Democratic primaries (FEC 1992) compared to 44.9 million for Bill Clinton in the general election. These figures provide a much more positive impression of participation levels than one gets by looking only at turnout percentages. Certainly, those percentages are much lower for presidential primaries than for general elections, but they are often higher than for non-presidential primaries. They vary greatly state-by-state and party-by-party, both because of differing state laws, party rules, and customs and because some primaries happen to be uncontested either late in the season or at any time against a popular incumbent. Nevertheless, voting totals in presidential primaries are impressive.

In this respect, the presidential nominating system now looks in fact though not in form much like the distinctively American method by which party nominees for most nonpresidential offices are selected. Presidential primaries determine nominations almost as surely as do direct primaries for other offices even though the former do so through elected delegates to conventions. I observe the similarity in order to stress the extent to which the 1972-1992 presidential nominating system conforms to candidate selection practices generally prevailing in the United States during most of this century. Hence, prior to 1972, presidential nominations should be understood as the great exceptions insofar as they could still be determined by means other than primary victories. Even then, as we know, a few presidential primaries were occasionally influential if not absolutely decisive under the mixed system of 1912-1968. Moreover, after 1952 nominations went to popular favorites, as determined by primaries or public-opinion polls, without requiring more than one convention ballot. Brokered conventions may have practically ended even before that; one prescient commentator (Carleton 1957) argued that conventions chose popularly-determined favorites regularly after 1924. But whenever we date the beginning of the change from brokered conventions, popular choice was not institutionalized before the last twenty years. Only in this period is it clear that primaries regularly dominate, instead of waxing and waning in number as they did from 1912 to 1968 , and that delegates chosen in those primaries can be expected to be firmly pledged to particular candidates. 


\section{II}

Moving now to presidential nominating systems that are alternatives to the present system, I describe only proposals that would fundamentally transform selection by our serially scheduled events dominated by primaries. Thus, I exclude modifications of the present system like those frequently made since 1972. However significant their impact, now or in the future, such modifications are not designed to transform the system into something essentially different, as are the options that I now take up. My list of six may not exhaust all of the possibilities although I have tried to do so, apart perhaps from certain hybrids and apart also from an elimination of party roles by Perot-style nominations. The options are considered roughly from least to most participatory.

1. The congressional caucus, used through 1824 to select presidential nominees, is anachronistic, but I begin with it because it is a well-defined peer review marker at the non-participatory end of the spectrum. U.S. Senators and Representatives of a given party surely know their colleagues, excolleagues and many other current and past governmental officeholders. They have unusual opportunities to evaluate the political abilities of many prospective nominees in the context of the national problems with which presidents must deal. Members of Congress thus resemble the national legislators who in parliamentary regimes choose prime ministers or potential prime ministers when electing their party leaders. British Conservative M.P.s are a familiar case in point. Serviceable as their practice may still be in Britain and in several other parliamentary nations, its failure to survive beyond 1824 in the United States helps to explain why peer review in any relatively pure form is unlikely in our political culture. The demise of the old congressional-caucus method came not only from its challenge to the constitutional separation of powers, but also, more significantly, from its challenge to the increasing democratization of American politics. Members of Congress, as a Washington establishment, were too narrow an elite to be entrusted with presidential nominations.

2. Peer review is a slightly more serious option if other party leaders are added to Senators and Representatives on a presidential nominating body. These other leaders might include a party's governors, mayors, and state legislative leaders as well as national party committee members and state party officials. Numbers thus would be large enough to constitute a convention rather than a caucus or committee, but the body nevertheless would differ from the old nineteenth-century party conventions in that its 
membership would be entirely ex officio, and thus would exclude the occasional popular participatory elements produced by the old local caucuses and state conventions. All of the delegates in the plan I hypothesize would be like those that the Democratic party has included as "unpledged superdelegates" at its conventions of 1984, 1988, and 1992. But instead of being only a minority unable to overturn a choice already made by primary voters, ex officio delegates now would be the only delegates, and thus the only nominators. To establish a nominating convention of this kind is legally within the power of a national party. No congressional or state legislation is necessary for a party that wants to ignore primaries and simply seat delegates chosen by its own rules. Politically, however, it is far from realistic to think that a major party would risk the public opprobrium certain to follow from an empowerment of a party's own leadership and the wholesale rejection of popular participation in the nominating process. Understandably, the Democratic party was unwilling to provide more than about 15 per cent of its delegate slots for unpledged ex officio delegates, 1984-1992, thus not posing a clear challenge to the dominance of pledged delegates chosen in primaries, despite a desire to do so.

3. No more feasible politically than a nominating convention composed entirely of delegates serving by virtue of their public or party offices is a return to the conventions of 1836-1908. In that pre-primary era, delegates were chosen by party committees or more often by the caucus-convention method that provided opportunities for activists to participate (sometimes in fairly large numbers), but also (and probably more often) for party leaders to dominate the delegate-selection process. Many delegates were not pledged to likely presidential candidates, and this facilitated brokered nominations of candidates, including some who had demonstrated little popular support before the convention but who could unite party followers. Such brokered nominations are an objective of those who would restore something like the old convention system. Brokerage becomes synonymous with peer review.

Whether peer review now could be established by substituting caucuses for primaries in delegate selection is most unlikely. Many caucuses would, like Iowa's, resemble small primaries in which presidential candidates competed for the support not only of party activists but of many others, in and out of various interest groups, who were willing to attend caucuses. Moreover, caucuses would be subject to much less control by party leaders than was true in the nineteenth century. Nor would caucuses consist only of regularized dues-paying party members, even where they were present. Caucuses would function like primaries in at least one important respect. They would produce delegates pledged to serious presidential candidates, not merely 
favorite sons, and such candidates could claim popular mandates similar to those of present-day winners of primaries. Although delegates won in caucuses would represent fewer voters than do delegates now won in primaries, the candidate with the most caucus-provided delegates legitimately could claim, in the absence of primaries, the party nomination on the ground of having been victorious in the only popularly-conducted process that existed. Whether a nomination thus achieved would be superior to that now made by primary voters is arguable, but it surely differs from the brokered nominations sought by believers in the old system.

In any case, no one believes that a major national party will challenge public expectations by insisting that all of its convention delegates be elected by caucuses rather than primaries. Like the equally legal power of a national party to seat only ex officio delegates, the authority of a party to seat only caucus-selected delegates is doomed to disuse.

4. An apparently more realistic option, and certainly one much more often suggested, is a mixture of primaries, caucuses, and other delegateselection devices resembling the system that prevailed from 1912 through 1968. Versions of this option vary considerably, but their common element is a reduction of the number of primaries without completely eliminating them or their possible influence. Caucuses are proposed as the principal substitute for primaries although even less participatory methods, such as those for ex officio delegates, also may be proposed along with more caucuses. Some proponents of a mixed system hope to restore brokered conventions, at least occasionally. That hope reflects highly wishful thinking, in light of the absence even under the old mixed system of any truly brokered convention after 1952, and no classic instance of the rejection of a popular favorite for a dark-horse candidate after 1924. Lately, as indicated in the previous section, brokered conventions are still more remote possibilities given the tendency of caucuses, like primaries, to commit delegates to presidential candidates rather than to the control of state and local leaders.

Brokered conventions, however, are not the purpose of one set of champions of a revived mixed system. Therefore, they are undeterred by the prospect of caucuses, along with district and state conventions, producing pledged delegates much as primaries do. They simply prefer caucuses to primaries (Burns 1990, 112-13, 125-27; Burns 1980, 198-99); and thus what they assume will be the influence of party activists instead of the larger number of less organized party primary voters. The preference usually reflects an ideological conviction that Democratic activists will favor liberal candidates and that Republican activists will favor conservative candidates. Expectations here are probably correct much of the time, provided that one 
counts special interest groups, which often flood caucuses, as genuinely of the left or right ideologically.

Undeniably, caucuses of the now well-established open, participatory kind are taken over readily by relatively small numbers of well-organized persons. Doing so is facilitated because caucus turnouts, even at welladvertised media events, are much lower than primary turnouts (on average about one-sixth the size, according to Marshall 1989, 9). For example, in 1988, when both Iowa and Wisconsin were seriously contested by Democratic presidential candidates, the Iowa Democratic caucus turnout was only one-eighth the size of the Wisconsin Democratic primary turnout although Iowa's population is over half of Wisconsin's (Pomper 1989, 40). To be sure, small caucus turnouts - and most caucus turnouts are much lower than Iowa's - do not make them less desirable than primaries in the eyes of their proponents. They surely can argue that the lower numbers reflect quality of participation, since greater interest and commitment are required for caucus attendance than for casting primary ballots.

The representativeness of caucus participants is another matter. Such evidence as we have suggests that caucuses, more than primaries, overrepresent ideological extremes and organized interests (Miller 1988, 12530); Rapoport, Stone and Abramowitz 1991, 202 n 14; Schier 1980, 30912). Understandably, politicians, notably elected officeholders, often have favored primaries, if only as a lesser evil than open caucuses, since their goal is to nominate candidates attractive enough to centrists to be electable. Here indeed is one explanation for the rapid increase in presidential primaries during the 1970s, when the new Democratic party rules, along with popular opinion, precluded the old closed caucuses. Unforeseen by Democratic reformers on the McGovern-Fraser Commission, who wanted to save the caucuses by opening them, their rule changes led to additional primaries in 1972 and especially in 1976 following the results of certain open caucuses in 1972. Despite a few retreats in the middle 1980s, primaries increased again in 1988 and 1992 partly in reaction to the successes in caucuses of perceived extremist candidates-Jesse Jackson, and Pat Robertson (Hertzke 1993, 157-201). Michigan, Washington, and Minnesota then provided presidential primaries after recent experiences with caucus-based selection of delegates.

Plainly, the political tide runs strongly against large-scale replacement of primaries by caucuses insofar as the choice remains in state and state party hands. Therefore, supporters of more caucuses look to the undoubted power of a national party to institute the change either by insisting that no more than a specified minority of each state's delegates be chosen in primaries, or by allowing no more than a minority of states (Burns 1990, 
126-27, suggests ten) to hold primaries in any given election year. The first of these two proposals strikes me as more nearly feasible than the second, but neither is well-calculated to achieve its purpose of reducing the impact of primary results. Would not the candidate who won most of the primaryelected delegates, even though they constituted a minority of all convention delegates, have so strong a claim to be the popular choice that he or she could not be refused the nomination without severe political repercussions? The claim would, it is true, be inferior to that now asserted by the winner of many more primary-derived delegates, but it would be the best available claim. Thus, we would have a less widely supported nominee than we now get. I know that caucus proponents want no such undesirable outcome. They are likely, however, to get it because they cannot reduce greatly at present the influence of primaries by limiting the number of delegates chosen by that method. Hence, I see no reason to support the option even if I were to concede - which I do not — that caucuses are qualitatively superior to primaries.

5. Turning from the several options plainly intended to eliminate or reduce large-scale voter participation in the nominating process, I consider a national primary in its several proposed forms. Such an event, unlike the suggested changes previously discussed, requires national legislation, and that itself is a radical innovation in a field so far left almost entirely to states, state parties, and the national parties. Constitutionally, however, Congress probably has the power to establish national direct primaries to choose party nominees for president, or to provide national primaries to elect pledged convention delegates to do the nominating. So, too, might Congress provide for regional primaries (say, one for each of our four time zones) that together would constitute a national primary, although held on several election dates spaced a few weeks apart.

All forms of a national primary share certain common problems. One is how to define voter-eligibility. Should Congress impose a nationally uniform rule to supersede the present practice by which each state (and sometimes each state party) defines its primary participants? Now, as we know, certain states require that party primary voters be enrolled in advance as party members, others require only a public declaration of party preference at the polls, and still others have no such requirements at all. Moreover, within those three broad categories, many variations exist, particularly with respect to the number of days before an election that one can change a party enrollment. A national eligibility rule would be an almost inevitable necessity if a party nomination were to be decided by majority or plurality of the total national popular vote in a party's national primary. Otherwise, the open-primary states could provide more voters in relation to their electorate 
than would closed-primary states in relation to theirs. A way around this problem, without imposing a national rule, would be to have national primaries that elected convention delegates, or even electors, state by statethat is, counting popular votes not nationally but only in each state, as we do for the electoral college when electing the president. I doubt, however, whether the electoral college method, firmly fixed though it seems, is so attractive that contemporary Americans would want to extend it to presidential primaries.

A second problem raised by a national primary is that it would favor already established national figures at the expense of less widely known candidates who under the present system are often able to gain attention by early victories in small or medium-sized states where campaigning is heavily personal and much less expensive than a national primary campaign. This is not, I grant, a problem for some proposers of a national primary; rather, they see an advantage in confining the nominating contest to established national politicians, thereby eliminating the outsiders like George McGovern and Jimmy Carter. It is hard, however, to argue that point openly, and even harder to argue it persuasively against the formidable political forces who would recognize themselves as cast out of contention by a national primary. Having four regional primaries might not be much better for outsiders.

Still another problem is the apparent irrevocability associated with the adoption of a national primary. Once instituted by congressional legislation, while no doubt subject to incremental modification, a national primary is most unlikely to be abolished. As the virtually ultimate step in the ratcheting democratization of the presidential nominating process, it would be even more difficult to abandon than the proliferating state primaries of the 1970s. Therefore, many of us, unable to see all the consequences, might well hesitate about taking the plunge into the uncharted waters of a national primary.

Finally, among a national primary's problems is its relation to the national party convention. Abolishing the latter is hardly a necessary accompaniment of a national primary. Even if a party's nominee were chosen by direct popular vote, a convention would serve the same purposes that it now does by way of platform-making and showcasing its nominee. Losing the present-day convention's merely formal ratification of the popular presidential nomination is not consequential. More troublesome is the composition of the convention if a direct national primary were used to select nominees. It would not make much sense to have delegates elected in anything like the current primaries and caucuses when the presidential nomination was decided in another primary. So, presumably, national convention delegates could now be party organizational choices of one sort or another. But would they then be responsive in adopting a platform, as delegates now are, to the 
presidential nominee? Possible incompatibility here suggests the advantages of a national party primary that elected pledged delegates instead of a direct primary that nominated a candidate by straight national popular vote.

Although, as suggested, electing pledged delegates in a national primary can in its nominating result be the practical equivalent of a national direct primary, it also is conceivable that a national convention of a different sort can be combined with a national primary so as to re-introduce an organizational influence in the nominating system. At least two serious proposals, qualifying in different ways the straight popular-choice principle, have emerged. One is to have a national party convention before a national primary, its delegates chosen as now in a manner prescribed by the individual states and empowered to certify for the subsequent national primary only those candidates who received at least 20 percent of the ballot cast by delegates (Mileur and White 1989, 20). Another version of this pre-primary convention, also with the 20 percent plateau, would ensure a large organizational presence and then would restrict the primary electorate to a welldefined party membership (Pomper 1992, 147). The model for both versions is the Connecticut law for state and congressional nominations; that law often produces a nominee without the need for any primary when only the winner of a convention majority has over 20 percent of the delegate voters. Those who would adapt the law to presidential nominations may not anticipate the same easy ride for most national convention favorites, but they surely aim to eliminate maverick candidates and to help organizational choices. Ingeniously, proponents of the pre-national primary convention seek to limit the impact of popular electoral participation while expanding it to the national level. Whether organizational influence actually could be achieved thus nationally, as in Connecticut, is most uncertain.

The second proposal for an enhanced organizational influence along with a national primary is to have the national party convention after a national primary in which two-thirds of the convention's delegates had been elected and pledged to candidates according to their vote in each of the states. The other third of the delegates would come from party officials and public officeholders, somewhat differently defined by Ladd (1980), who developed the plan and then abandoned it, than by Reichley (1992, 428-431), who much more recently championed it. Reichley acknowledges that the primary winner occasionally would be so far ahead and widely accepted that the convention, as now, would ratify the popular choice, but he also calculates that support at the time of the primary often would be so divided among several candidates that the convention, featuring considerable peer review, could make the choice. In other words, the national primary is thought less likely to produce a clear winner than the present system of 
serial state primaries. Such thinking rests on the dubious assumption that generally no one candidate would have the recognition and the resources to win in more than one section of the country. It seems to me, however, that certain kinds of candidates, probably different from those able to emerge successfully from our serial primaries, could become winners in more than one section. "Winning" would be defined by the news media as "the most votes"- especially, but not only, if the leader's vote total netted half or more of the two-thirds of the delegates chosen in the national primary. For a winner in that well-publicized sense to be rejected by a convention, crucially tipped by peer-reviewing party officers and officeholders, strikes me as so imprudent a defiance of popular opinion as to be uncharacteristic of American politicians.

6. Remaining among conceivable options is a direct primary linked to direct popular election of the president. I consider it separately from the other versions of a national primary just discussed because it certainly requires a constitutional amendment, not merely congressional statute, and because it need not involve party primaries. The model is the French Fifth Republic's presidential election system: a first ballot contested by as many candidates as secure nomination by 100 national, regional, or local officeholders; and a second ballot contested only by the top two finishers on the first-ballot, unless one had won an absolute majority on the first ballot. Parties, of course, endorse and support particular candidates in the first as well as the second election, but their decision is made organizationally and not in anything like an American party primary. Adapted to American experience, one can imagine party conventions, involving delegates chosen under our various procedures, that endorsed candidates before the first ballot. But we also readily can imagine unendorsed candidates, some with party affiliations and some independents, entering the same contest-assuming, as I would, that our law allowed unendorsed candidates to be nominated by petition (probably of ordinary citizens rather than only public officeholders). Here the opportunity for a Ross Perot is evident, though in competition against party candidates on the first, or primary, ballot.

My guess is that something like the French Fifth Republic's system would emerge from an American constitutional convention that was establishing a national government for the first time in 1993, rather than in 1787. The electoral college method would not commend itself to founders of a new order in the late twentieth century. But we are long past starting from scratch. Rather, we confront an originally nondemocratic method that appears adaptively compatible with a satisfactorily democratic election of the president. Thus, pressure sufficient to abolish the electoral college in 
favor of direct popular election does not exist. Interest even in thinking about an implementing constitutional amendment arises only when the electoral college is thought likely to fail to produce a winner (as seemed possible in 1968 and again briefly in 1992), or fail to produce a winner who also had a plurality of popular votes (as almost happened in 1976). Significantly, after the close call in 1968, the electoral college's abolition was discussed seriously, and so was the coupling of a national primary with the proposed direct popular election. Still, no proposed amendment actually was submitted by Congress to the states. I infer that only an actual failure to produce a clear winner, not just a close call, would provide the popular momentum for a constitutional amendment. Only then, but probably then, would there also be serious consideration of the kind of national primary that resembles the French model.

III

Having, I hope, argued persuasively against the desirability or feasibility of the several alternative presidential nominating systems, I shall conclude by returning briefly to an advantage of the present system. It has a well-demonstrated capacity for incremental change and experimentation undertaken by national parties, state legislation, and state parties. Primaries can be increased or decreased in numbers, their rules altered in many ways, and their scheduling shifted so as to shorten the nominating season or to cluster some, but not all, contests by region. For example, a national party that really wanted to reduce the importance of New Hampshire could refuse to seat delegates chosen before a proclaimed starting date. Calling attention to such possibilities at the end of my paper suggests that, like almost everyone else, I believe that our presidential nominating system might be improved even though I would seek such improvement without adopting an alternative system.

\section{REFERENCES}

Burns, James MacGregor. 1980. Party Renewal: The Need for Intellectual Leadership. In Gerald M. Pomper, ed., Party Renewal in America. New York: Praeger. . 1990. Cobblestone Leadership. Norman: University of Oklahoma Press.

Carleton, William G. 1957. The Revolution in the Presidential Nominating Convention. Political Science Quarterly 72: 224-40.

Federal Election Commission. 1992. 1992 Presidential Primary Election Results. Washington: Federal Election Commission.

Hertzke, Allen D. 1993. Echoes of Discontent. Washington: Congressional Quarterly Press.

Ladd, Everett Carll. 1980. A Better Way to Pick Our Presidents. Fortune 101: 132-42. 


\section{2 | Leon D. Epstein}

Marshall, Thomas R. 1989. Presidential Primaries and Caucuses Reconsidered. Paper presented at the annual meeting of the Midwest Political Science Association, Chicago, IL.

Mileur, Jerome J. and John Kenneth White. 1989. Where Angels Fear to Tread: Toward a Larger National Role in a Federal System of Presidential Nomination. Paper presented at the annual meeting of the Midwest Political Science Association, Chicago, IL.

Miller, Warren E. 1988. Without Consent: Mass-Elite Linkages in Presidential Politics. Lexington: University of Kentucky Press.

Polsby, Nelson W. 1983. Consequences of Party Reform. New York: Oxford University Press.

Pomper, Gerald M. 1989. The Presidential Nominations. In Gerald M. Pomper, ed., The Election of 1988. Chatham, NJ: Chatham House Publishers.

1992. Passions and Interests. Lawrence: University Press of Kansas.

Rapoport, Ronald B., Walter J. Stone, and Alan I. Abramowitz. 1991. Do Endorsements Matter: Group Influence in the 1984 Democratic Caucuses. American Political Science Review 85: 193-203.

Reichley, A. James. 1992. The Life of the Parties. New York: The Free Press.

Schier, Steven E. 1980. The Rules and the Game: Democratic National Convention Delegate Selection in Iowa and Wisconsin. Washington, DC: University Press of America. 